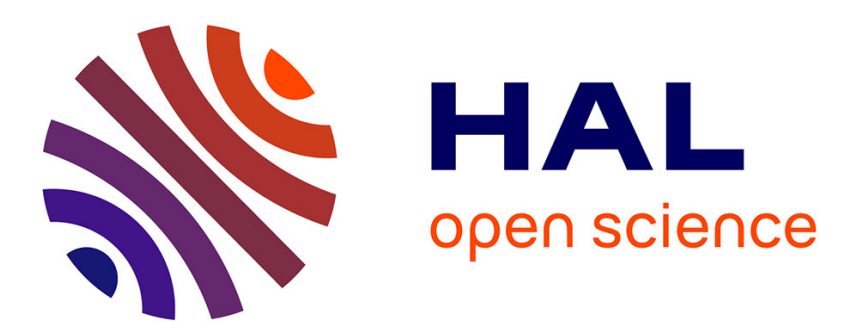

\title{
Carbon steady-state model of the planktonic food web of Lake Biwa, Japan
}

\author{
Nathalie Niquil, Gretta Bartoli, Jotaro Urabe, George A. Jackson, Louis
} Legendre, Christine Dupuy, D. M. Kumagai

\section{To cite this version:}

Nathalie Niquil, Gretta Bartoli, Jotaro Urabe, George A. Jackson, Louis Legendre, et al.. Carbon steady-state model of the planktonic food web of Lake Biwa, Japan. Freshwater Biology, 2006, 10.1111/j.1365-2427.2006.01595.x . hal-01248033

\section{HAL Id: hal-01248033 \\ https://hal.science/hal-01248033}

Submitted on 26 Dec 2016

HAL is a multi-disciplinary open access archive for the deposit and dissemination of scientific research documents, whether they are published or not. The documents may come from teaching and research institutions in France or abroad, or from public or private research centers.
L'archive ouverte pluridisciplinaire HAL, est destinée au dépôt et à la diffusion de documents scientifiques de niveau recherche, publiés ou non, émanant des établissements d'enseignement et de recherche français ou étrangers, des laboratoires publics ou privés. 


\title{
Carbon steady-state model of the planktonic food web of Lake Biwa, Japan
}

\author{
NATHALIE NIQUIL,${ }^{*}$ GRETTA BARTOLI,${ }^{*}{ }^{+}$JOTARO URABE,${ }^{\ddagger}$ GEORGE A. JACKSON,$\$$ \\ LOUIS LEGENDRE," CHRISTINE DUPUY* AND M. KUMAGAI** \\ *Centre de Recherche sur les Ecosystèmes Littoraux Anthropisés, Université de La Rochelle, La Rochelle, France \\ ${ }^{\dagger}$ Institut für Geowissenschaften, Universität Kiel, Kiel, Germany \\ ${ }^{\ddagger}$ Ecology and Evolutionary Biology, Graduate School of Life Sciences, Tohoku University Biological Buildings, Aoba, Sendai, Japan \\ ${ }^{\S}$ Department of Oceanography, College of Geosciences, Texas AEM University, College Station, TX, U.S.A. \\ 'Laboratoire d'Océanographie de Villefranche, Villefranche-sur-Mer, France \\ ${ }^{* *}$ Lake Biwa Environmental Research Institute, Otsu, Shiga, Japan
}

\section{SUMMARY}

1. A steady-state model of carbon flows was developed to describe the summer planktonic food web in the surface mixed-layer of the North Basin in Lake Biwa, Japan. This model synthesised results from numerous studies on the plankton of Lake Biwa.

2. An inverse analysis procedure was used to estimate missing flow values in a manner consistent with known information. Network analysis was applied to characterise emergent properties of the resulting food web.

3. The system strongly relied on flows related to detrital particles. Whereas primary production was mainly by phytoplankton $>20 \mu \mathrm{m}$, microzooplankton were active and mainly ingested detritus and bacteria.

4. The main emergent property of the system was strong recycling, through either direct ingestion of non-living material by zooplankton, or ingestion of bacteria after degradation of detritus to release dissolved organic carbon.

Keywords: detritus, food web, lake, plankton, static model

\section{Introduction}

In spite of the wealth of biological information on the pelagic communities in lake ecosystems, the available data in single lakes have rarely been assembled into food webs. Even if trophic interactions, nutrient recycling and material budget have been described roughly, details on material flows among community components are unknown. In order to understand the processes that sustain ecosystems and to assess the role of each process, it is necessary to synthesise biological data in trophic webs, illustrating quantitatively the material flows that connect community components. However, it is almost impossible to

Correspondence: Nathalie Niquil, Centre de Recherche sur les Ecosystèmes Littoraux Anthropisés, UMR 6217, Université de La Rochelle, Av. Michel Crépeau 17042 La Rochelle Cedex 1, France. E-mail: nniquil@univ-lr.fr obtain all of these flows from field observations because of methodological problems in measuring everything. A modelling approach can overcome this difficulty. The last decade has seen the rapid development of modelling methods aimed at describing and analysing the flows of matter and energy in aquatic ecosystems. Among these approaches, Vézina \& Platt (1988) developed an inverse analysis technique to describe marine planktonic food webs in a model that coupled the flows of carbon and nitrogen. The method makes it possible to estimate the flows of material between trophic components that are difficult to determine directly and thus to estimate quantitatively a complete set of flows within the food web. Because of the power of inverse analysis, a number of studies have applied this approach to analyse flows among trophic components in various aquatic ecosystems, which include lakes (Vézina \& Pace, 1994), marine sediments (Eldridge \& Jackson, 
1993) and atoll lagoons (Niquil et al., 1998, 1999, 2001). These studies show that inverse analysis is useful for determining the relative importance of trophic channels that have not been quantitatively detected by conventional field observations. It must be noted, however, that substantial knowledge on the biological processes among trophic components of an ecosystem is necessary to apply inverse analysis successfully.

Lake Biwa is the largest lake in Japan and one of the ancient lakes of the world. It supplies water to 14 million people living in Kinki regions, which contain $0.25 \%$ of the global human population. As a result, Lake Biwa is a very important ecosystem, both ecologically and economically. A number of studies have described the seasonal succession and population dynamics of phytoplankton, bacteria and micro(mostly protozoans) and mesozooplankton (mostly crustaceans) (Nagata, 1984, 1986; Kawabata, 1987; Nakano, 1992; Kawabata \& Urabe, 1996; Gurung et al., 2001; Yoshida et al., 2001a). Trophic interactions between these components have been intensively studied during the past 20 years (Nagata et al., 1996; Urabe et al., 1996; Gurung, Nakanishi \& Urabe, 2000; Yoshida et al., 2001b; Kagami et al., 2002). Several studies have examined the relative importance of factors regulating the production, growth and abundance of phytoplankton (Frenette, Vincent \& Legendre, 1996; Robarts et al., 1998; Urabe et al., 1999a; Kagami \& Urabe, 2001) and bacteria (Nagata, 1988; Nakano, 1992; Gurung \& Urabe, 1999; Gurung et al., 2001), and the roles of micro- (mostly protozoans: Nakano, 1994; Takahashi et al., 1995a) and mesozooplankton (mostly metazoans: Urabe, Nakanishi \& Kawabata, 1995) in nutrient regeneration. In addition, allochthonous inputs (Yoshimizu et al., 2002) and sinking fluxes of organic matters (Nakanishi et al., 1992; Takahashi et al., 1995b; Yoshimizu et al., 2001) were measured in conjunction with primary production and grazing experiments.

The extensive observations made in Lake Biwa make inverse analysis possible. In the present study, we applied this method to the pelagic community in order to describe quantitatively the full set of carbon flows between trophic components. We consider only carbon flows because ecological (trophic interactions) and physiological (metabolism) processes can be easily described in terms of carbon. We focus on the layer above the thermocline during summer in the
North Basin of the lake because most field data correspond to this spatio-temporal window.

\section{Methods}

Study site

Lake Biwa is located on Honshu Island, Japan at $\left(35^{\circ} 11.5^{\prime} \mathrm{N}, 135^{\circ} 58.8^{\prime} \mathrm{E}\right)$. This mid-latitude temperate zone lake is divided in two basins (Fig. 1), the mesotrophic North Basin $\left(616 \mathrm{~km}^{2}\right.$, average depth of $45.5 \mathrm{~m})$ and the eutrophic South Basin $\left(58 \mathrm{~km}^{2}\right.$; average depth of $3.5 \mathrm{~m}$ ). It has a maximum depth of $104 \mathrm{~m}$. Water enters the lake through 34 rivers, with more than $99 \%$ of this water arriving in the North Basin. Epilimnetic water from the North Basin flows into the South Basin, from which it flows into the Seta River.

\section{Inverse analysis and application}

Methods. The inverse approach of Vézina \& Platt (1988) describes each trophic component (compartment) in terms of all the possible flows in to or out of it. While non-steady-state conditions can be described by including flows that accumulate mass, we have

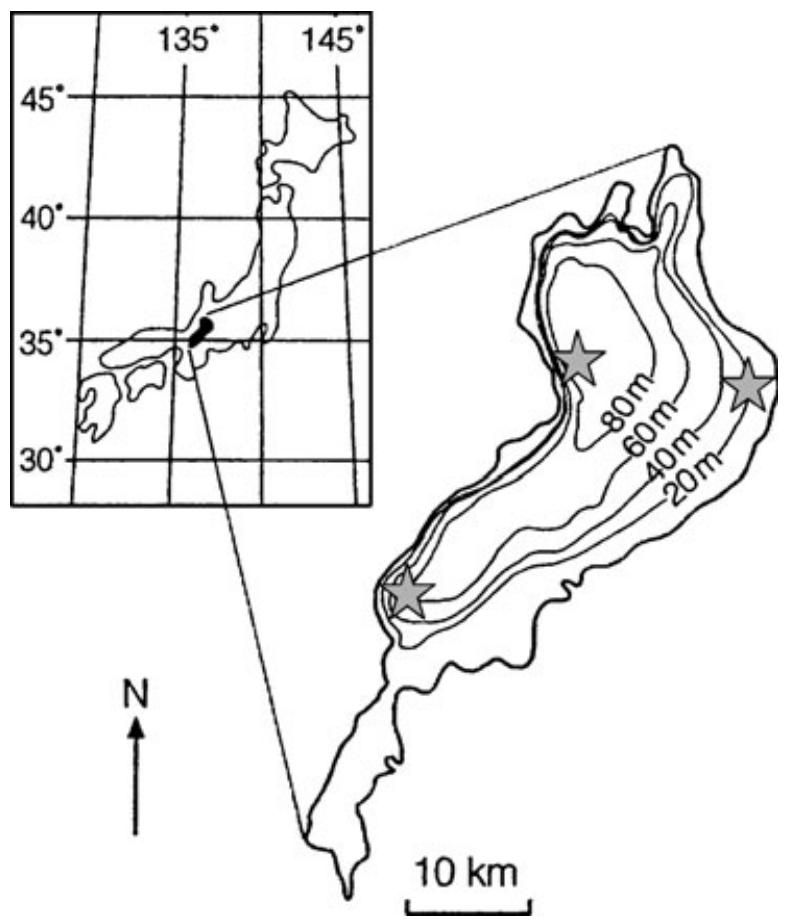

Fig. 1 Map of Lake Biwa showing the sampling sites (stars) used in the present study (from Frenette et al., 1996). 
1572 N. Niquil et al.

made a steady-state assumption that does not account for growth. The total flows in and out of each compartment must be equal for the system to be in balance, which leads to a mass-balanced equation describing each compartment. Field determinations of rates of planktonic processes, such as photosynthetic and grazing rates, allow us to incorporate data into the model by formulating additional linear equations that express the observations in terms of flows. The equations describing the system and the data can be written:

$$
A \times r=b
$$

where $A$ is a matrix of coefficients, $r$ is the vector of flows (unknowns) and $b$ contains the solution vector of the equalities.

Because the number of flows (unknowns, here 38) exceeds the number of equations (mass balance + data estimates, here $8+18$ ), the system is mathematically underdetermined and has an infinity of solutions. Vézina \& Platt (1988) applied two additional criteria to obtain a single solution. The first was a set of constraints limiting the rates and efficiencies of biological processes. These were expressed as inequalities for linear combinations of flows. The system of inequalities can be written:

$$
G \times r \geq h
$$

where $G$ is a matrix of coefficients and $h$ is the boundaries vector of inequalities.

Applying such constraints reduced the domain of solutions, but it still allowed an infinite number of possible solutions. The second criterion was based on a parsimony principle which assumes that the 'best' values for the flows are those which form the smallest Euclidean norm (Vézina, 1989). These two additional criteria led to a single solution vector describing the flows between pairs of compartments of the system or between components that are in and out of the system. The algorithmic technique was described in Vézina \& Platt (1988).

Compartments. We separated organic matter in the surface mixed layer into eight compartments (Table 1). The six living compartments were: three size classes of phytoplankton, two size classes of zooplankton and one class of heterotrophic bacteria; the two non-living compartments were particulate and dissolved organic matter. Mixotrophic organisms
Table 1 Descriptions and abbreviations of the eight food web compartments used in the model

\begin{tabular}{ll}
\hline Description & Abbreviation \\
\hline Phytoplankton $<2 \mu \mathrm{m}$ & ph1 \\
Phytoplankton $2-20 \mu \mathrm{m}$ & ph2 \\
Phytoplankton $>20 \mu \mathrm{m}$ & ph3 \\
Heterotrophic bacteria & bac \\
Microzooplankton (Zooplankton $<100 \mu \mathrm{m}$ ) & mic \\
Mesozooplankton (Zooplankton $>100 \mu \mathrm{m})$ & mes \\
Detritus (non-living material $>0.7 \mu \mathrm{m})$ & poc \\
Dissolved organic carbon & doc \\
(non-living material $<0.7 \mu \mathrm{m})$ & \\
\hline
\end{tabular}

present in the lake (e.g. Uroglena americana, Urabe, Gurung \& Yoshida, 1999b) were not collected into a specific compartment but the flows associated with them were allocated to phytoplankton or zooplankton according to metabolic characteristics: primary production was allocated to phytoplankton and phagotrophic intake to zooplankton. Mixotrophs were neglected when calculating biomass in compartments.

Possible flows. The group of allowed flows, all positive, makes up what is called the a priori model (listed in Table 2). Although bacteria cannot consume detritus directly, they can consume it indirectly by consuming dissolved organic carbon (DOC) solubilised from detritus. Bacteria can be consumed by both microzooplankton and mesozooplankton (e.g. nonpigmented nano-flagellates and Daphnia galatea, Nagata, 1988). Mesozooplankton can also consume all sized of phytoplankton but microzooplankton can consume only the two smaller groups (ph1, ph2). The smallest cells (ph1 and bac) are not lost by sinking. Carbon from bacteria that die, such as from viral lysis, flows directly to DOC. Exchange of detritus and DOC outside the system is allowed, with information about the net exchange included as data. Such exchanges are primarily by river flows, but do include exchanges between inshore and offshore areas and between the surface mixed layer and deep water and sediments.

Available data and their incorporation into model equations. The three sampling sites selected (stars in Fig. 1) were located in the North Basin and had bottom depths of 20-70 m. We used data collected between June and September. The thermocline depth varied between approximately 10 and $20 \mathrm{~m}$ (Nagata, 1988) and approximately 15 to $20 \mathrm{~m}$ (Mitamura, 
Table 2 Flows of the steady-state model, with abbreviations used in Fig. 2. For each flow, the value given is obtained by the inverse analysis

\begin{tabular}{|c|c|c|c|c|}
\hline Description & Flow number & Flow name & $\begin{array}{l}\text { Inferred value } \\
\left(\mathrm{mg} \mathrm{C} \mathrm{m}^{-2} \text { day }^{-1}\right)\end{array}$ & Sensitivity Index \\
\hline Gross phytoplankton production for ph1 & 1 & gpp-ph1 & 155 & 0.61 \\
\hline Gross phytoplankton production for ph2 & 2 & gpp-ph2 & 323 & 0.21 \\
\hline Gross phytoplankton production for ph3 & 3 & gpp-ph3 & 1100 & 0.07 \\
\hline Respiration by ph1 & 4 & ph1-res & 50 & 0.77 \\
\hline Grazing of ph1 by microzooplankton & 5 & ph1-mic & 24 & 2.93 \\
\hline Grazing of ph1 by mesozooplankton & 6 & ph1-mes & 69 & 0.07 \\
\hline ph1 detrital POC production & 7 & ph1-poc & 10 & 0.71 \\
\hline DOC excretion by ph1 & 8 & ph1-doc & 2 & 0.71 \\
\hline Respiration by ph2 & 9 & ph2-res & 91 & 0.66 \\
\hline Grazing of ph2 by microzooplankton & 10 & ph2-mic & 0 & - \\
\hline Grazing of ph2 by mesozooplankton & 11 & ph2-mes & 204 & 0.04 \\
\hline ph2 detrital POC production & 12 & ph2-poc & 23 & 0.06 \\
\hline DOC excretion by ph2 & 13 & ph2-doc & 5 & 0.06 \\
\hline ph2 sinking & 14 & ph2-out & 0 & - \\
\hline Respiration by ph3 & 15 & ph3-res & 352 & 0.12 \\
\hline Grazing of ph3 by mesozooplankton & 16 & ph3-mes & 209 & 0.07 \\
\hline ph3 detrital POC production & 17 & ph3-poc & 429 & 0.54 \\
\hline DOC excretion by ph3 & 18 & ph3-doc & 65 & 2.83 \\
\hline ph3 sinking & 19 & ph3-out & 45 & 0.07 \\
\hline Microozooplankton respiration & 20 & mic-res & 185 & 0.11 \\
\hline Grazing of microzooplankton by mesozooplankton & 21 & mic-mes & 81 & 0.14 \\
\hline Microzooplankton egestion & 22 & mic-poc & 417 & 0.11 \\
\hline DOC excretion by microzooplankton & 23 & mic-doc & 124 & 0.58 \\
\hline Mesozooplankton respiration & 24 & mes-res & 205 & 0.10 \\
\hline Mesozooplankton egestion & 25 & mes-poc & 437 & 0.11 \\
\hline DOC excretion by mesozooplankton & 26 & mes-doc & 145 & 0.46 \\
\hline Grazing of mesozooplankton by larger organisms & 27 & mes-out & 149 & 0.11 \\
\hline DOC consumption by bacteria & 28 & doc-bac & 920 & 0.10 \\
\hline Respiration by bacteria & 29 & bac-res & 460 & 0.06 \\
\hline Grazing of bacteria by microzooplankton & 30 & bac-mic & 422 & 0.05 \\
\hline Grazing of bacteria by mesozooplankton & 31 & bac-mes & 25 & 0.27 \\
\hline Bacteria mortality & 32 & bac-doc & 13 & 6.16 \\
\hline Non-living POC dissolution to DOC & 33 & poc-doc & 494 & 0.24 \\
\hline Grazing of non-living POC by microzooplankton & 34 & poc-mic & 360 & 0.25 \\
\hline Grazing of non-living POC by mesozooplankton & 35 & poc-mes & 349 & 0.22 \\
\hline Sinking of non-living POC & 36 & poc-out & 137 & 0.12 \\
\hline Net import of POC (import-export) & 37 & out-poc & 23 & 0.25 \\
\hline Net import of DOC (import-export) & 38 & out-doc & 73 & 0.20 \\
\hline
\end{tabular}

Bold values are directly determined by field observations (Table 3). res, respiration; gpp, gross primary production; out, outside the system considered. The Sensitivity Index gives the average value for all the simulations of the sensitivity analysis.

Kawashima \& Maeda, 2000), deeper than the euphotic zone (8-11 m; Mitamura et al., 2000). In order to describe all flows on an areal basis $\left(\mathrm{mg} \mathrm{C} \mathrm{m}^{-2} \mathrm{day}^{-1}\right)$, we integrated volumetric data from the surface to $20 \mathrm{~m}$. Data that we used were in published studies (Table 3). Their translation into linear combinations of flows is given in Table 4 .

In order to balance the flows in and out of the total system, we had to modify the primary production estimates. Yoshimizu et al. (2001) estimated primary production rates of $990 \mathrm{mg} \mathrm{C} \mathrm{m}^{-2}$ day $^{-1}$ for microphytoplankton (ph3) and $430 \mathrm{mg} \mathrm{C} \mathrm{m}^{-2}$ day $^{-1}$ for smaller phytoplankton $(\mathrm{ph} 1+\mathrm{ph} 2)$. Note that as they estimated the primary production rates using ${ }^{13} \mathrm{C}$ by incubating lake water for $4 \mathrm{~h}$, the measured rate is between net and gross production rates. Recent estimates for a pelagic site indicated that the annual import of allochthonous organic matter averaged $46 \mathrm{~g}$ $\mathrm{C} \mathrm{m}^{-2}$ year $^{-1}$, while lateral export was $11 \mathrm{~g}$ $\mathrm{C} \mathrm{m}{ }^{-2}$ year $^{-1}$ (Urabe \& Yoshioka, 2006). The difference 
Table 3 Values used for the inverse analysis, calculated from published field observations. Vertical water-column integration was over the mean depth of the layer above the thermocline, i.e. $20 \mathrm{~m}$. Abbreviations are from Table 1

\begin{tabular}{lcl}
\hline & $\begin{array}{c}\text { Value } \\
\left(\mathrm{mg} \mathrm{C} \mathrm{m}^{-2} \text { day }^{-1}\right)\end{array}$ & Reference \\
\hline Process & 496 & Yoshimizu et al. (2001) \\
Gross primary production of ph1 and ph2 & 1143 & Yoshimizu et al. (2001) \\
Gross primary production of ph3 & 182 & Yoshimizu et al. (2001) \\
Total sinking & 45 & Nakanishi et al. (1992) \\
Sinking of phytoplanktonic cells (ph2 and ph3) & 493 & Nakanishi et al. (1992) \\
Respiration of phytoplankton & 460 & Nakanishi et al. (1992) \\
Respiration of bacteria & 390 & Nakanishi et al. (1992) \\
Respiration of zooplankton & $6.6 \%$ of net & Nakanishi et al. (1992) \\
Exudation of DOC by the phytoplankton & primary production & \\
& 854 & Urabe et al. (1995) \\
POC egestion by zooplankton & 69 & Urabe et al. (1996), Kawabata \& Urabe (1996) \\
Grazing of ph1 by mesozooplankton & 204 & Urabe et al. (1996), Kawabata \& Urabe (1996) \\
Grazing of ph2 by mesozooplankton & 209 & Urabe et al. (1996), Kawabata \& Urabe (1996) \\
Grazing of ph3 by mesozooplankton & 447 & Gurung et al. (2002) \\
Bacterial production & 149 & Gurung et al. (2002) \\
Mesozooplankton production & 96 & Urabe \& Yoshioka (2006) \\
Carbon import as POC and DOC & $0.24 \times 96$ & Yoshimizu et al. (2002), Urabe \& Yoshioka (2006) \\
Carbon import as POC & $2 \times$ bacterial respiration & Gurung et al. (2002) \\
DOC consumption by bacteria & $30 \%$ & Nagata \& Okamoto (1988), \\
Bacteria grazing efficiency by & & Urabe \& Watanabe (1990), Yoshida et al. (2001a) \\
mesozooplankton as a percentage of & &
\end{tabular}

Table 4 Linear equations used as complements for the mass balance equations, to take into account field estimates. Abbreviations are from Tables $1 \& 2$

\begin{tabular}{ll}
\hline $\begin{array}{l}\text { Equation } \\
\text { number }\end{array}$ & Equation \\
\hline 1 & gpp-ph1 + gpp-ph2 $=496$ \\
2 & gpp-ph3 $=1143$ \\
3 & ph2-out + ph3-out + poc-out $=182$ \\
4 & ph2-out + ph3-out $=45$ \\
5 & ph1-res + ph2-res + ph3-res $=493$ \\
6 & bac-res $=460$ \\
7 & mic-res + mes-res $=390$ \\
8 & ph1-doc + ph2-doc + ph3-doc -0.066 gpp-ph1 - \\
& 0.066 gpp-ph2 -0.066 gpp-ph3 + \\
& 0.066 ph1-res +0.066 ph2-res +0.066 ph3-res $=0$ \\
9 & mic-poc + mes-poc $=854$ \\
10 & ph1-mes $=69$ \\
11 & ph2-mes $=204$ \\
12 & ph3-mes $=209$ \\
13 & bac-mic + bac-mes $=447$ \\
14 & mes-out $=149$ \\
15 & out-poc + out-doc $=35$ \\
16 & out-poc $=8.4$ \\
17 & doc-bac -2 bac-res $=0$ \\
18 & bac-mes -0.118 ph3-mes $=0$ \\
\hline
\end{tabular}

between the inflow and outflow of organic carbon (35 $\mathrm{g} \mathrm{C} \mathrm{m}^{-2}$ year $^{-1}=96 \mathrm{mg} \mathrm{C} \mathrm{m}^{-2}$ day $^{-1}$ ) represents the net annual import rate of allochthonous organic matter. Hence, the total organic carbon entering the system was $990+430+96=1516 \mathrm{mg} \mathrm{C} \mathrm{m}^{-2}$ day $^{-1}$. Total respiration rate of whole organisms (autotrophic and heterotrophic planktonic organisms) in the water column above the $20 \mathrm{~m}$ depth was $1343 \mathrm{mg}$ $\mathrm{C} \mathrm{m}^{-2}$ day $^{-1}$ (Nakanishi et al., 1992) and sinking rate of POC to deeper layers was $182 \mathrm{mg} \mathrm{C} \mathrm{m}^{-2}$ day $^{-1}$ (Yoshimizu et al., 2001). According to Urabe et al. (1996), net production of mesozooplankton from June to September corresponded to $10.5 \%$ of the primary production rate $\left(149 \mathrm{mg} \mathrm{C} \mathrm{m}^{-2} \mathrm{day}^{-1}\right)$. Assuming that all the net production of mesozooplankton was consumed by fish that left from the system, the sum of flows leaving the system was $1343+182+149=$ $1674 \mathrm{mg} \mathrm{C} \mathrm{m}^{-2}$ day $^{-1}$, a value larger than the total organic carbon entering the system. The two sets of measurements can be reconciled if the estimates of primary production rate mentioned above are increased by $11 \%$, thus being closer to gross production than net production. We increased, therefore, the gross primary production estimates of ph3 to 1100 and ph1 + ph2 to $478 \mathrm{mg} \mathrm{C} \mathrm{m}^{-2}$ day $^{-1}$, respectively, (total gross production: $1578 \mathrm{mg} \mathrm{C} \mathrm{m}^{-2} \mathrm{day}^{-1}$ ) in order to balance the inputs and outputs. No quantitative information was available on the microzooplankton grazing, except that its grazing on bacteria was close to 
bacterial production (Gurung et al., 2000). The rates of grazing by mesozooplankton on the three size classes of phytoplankton in the water column were calculated using the weight-specific grazing rate estimated by Urabe et al. (1996) and the average mesozooplankton biomass during summer at the same pelagic site (Kawabata \& Urabe, 1996).

From June to September, Eodiaptomus japonicus, Daphnia galeata and Diaphanosoma brachyurum were the dominant mesozooplankton species, comprising $66 \%, 20 \%$ and $8 \%$ of the mesozooplankton carbon biomass, respectively (Kawabata \& Urabe, 1996; Yoshida et al., 2001a). Although the latter two species can graze bacteria as efficiently as they can phytoplankton $>20 \mu \mathrm{m}$, the first one does not graze bacteria at all (Nagata \& Okamoto, 1988; Urabe \& Watanabe, 1990). Thus, roughly $70 \%$ (66 of 94 ) of mesozooplankton, in term of biomass, could not graze bacteria. Therefore, bacterial grazing by mesozooplankton was estimated assuming that their grazing efficiency on bacteria was $30 \%$ of that on phytoplankton $>20 \mu \mathrm{m}$.

Sinking of total organic matter and phytoplankton cells, respiration of living compartments, phytoplankton exudation of DOC and bacterial production rates for the summer were estimated from published data. The egestion rate of particulate organic carbon (POC) by zooplankton was calculated by multiplying the weight-specific particle elimination rate averaged from June to September $\left[0.33 \mathrm{mg}(\mathrm{mg} \mathrm{DW})^{-1}\right.$ day $^{-1}$, Urabe et al., 1995] by the average dry-weight at the surface (255 $\mu \mathrm{g}$ DW L ${ }^{-1}$, Urabe et al., 1996). Using this rate and the biomass distribution in the water column (Kawabata \& Urabe, 1996), the flow from zooplankton to POC was calculated.

Inequalities. Thresholds for biological and physical processes were applied to constrain the calculated values to ranges that resulted in realistic values. Vézina \& Platt (1988) and Vézina \& Pace (1994) gathered published information on different planktonic processes in order to estimate these realistic limits. We used their values (listed in Table 5) with one exception, i.e. the upper limit for phytoplankton respiration was modified from 30 to $32 \%$ of gross primary production to be consistent with values estimated by Nakanishi et al. (1992) in Lake Biwa.

\section{Network analysis}

The Network 4.2 Program (Ulanowicz, 1999) was used to calculate network indices for the carbon flows derived from our inverse analysis. The sum of all

Table 5 List of minimum and maximum values used as biological constraints for the inverse analysis. Abbreviations are from Tables 1 \& 2

\begin{tabular}{|c|c|c|c|}
\hline Constraint & Lower bound & Upper bound & Reference \\
\hline Respiration of ph1, ph2 and ph3 & $5 \%$ of gpp & $32 \%$ of gpp & $\begin{array}{l}\text { Vézina \& Platt (1988), } \\
\text { Nakanishi et al. (1992) }\end{array}$ \\
\hline Respiration of mic and mes & $3 \%$ of their ingestion & & Vézina \& Pace (1994) \\
\hline Ingestion of microzooplankton & & $\begin{array}{l}5.46 \times \text { Bmic } \times \exp \\
(0.0693 T)\end{array}$ & Vézina \& Platt (1988) \\
\hline Ingestion of mesozooplankton & & $\begin{array}{l}0.73 \times \text { Bmes } \times \exp \\
(0.0693 T)\end{array}$ & Vézina \& Platt (1988) \\
\hline $\begin{array}{l}\text { Degradation of dead phytoplankton to DOC } \\
\text { (ph1, ph2 and ph3) }\end{array}$ & $\begin{array}{l}10 \% \text { of } \\
(\mathrm{gpp}-\text { res }-\mathrm{poc})\end{array}$ & & Vézina \& Pace (1994) \\
\hline Exudation of DOC by ph1, ph2 and ph3 & $2 \%$ of (gpp - res $)$ & $55 \%$ of $(\mathrm{gpp}-\mathrm{res})$ & Vézina \& Pace (1994) \\
\hline Excretion of DOC by mic and mes & $10 \%$ of their ingestion & & Vézina \& Pace (1994) \\
\hline Assimilation efficiency of mic and mes [(ing - poc)/ing] & & $90 \%$ & Vézina \& Platt (1988) \\
\hline Net production efficiency of bac [(ing - poc - res)/ing] & $10 \%$ & $40 \%$ & Vézina \& Platt (1988) \\
\hline $\begin{array}{l}\text { Gross production efficiency of mic } \\
{[(\text { ing }- \text { poc }- \text { doc }- \text { res }) / \text { ing }]}\end{array}$ & $10 \%$ & $60 \%$ & Vézina \& Platt (1988) \\
\hline $\begin{array}{l}\text { Gross production efficiency of mes } \\
{[(\text { ing }- \text { poc }- \text { doc }- \text { res }) / \text { ing }]}\end{array}$ & & $40 \%$ & Vézina \& Platt (1988) \\
\hline All flows are non-negative & 0 & & \\
\hline
\end{tabular}

Bmic = biomass of microzooplankton $\left[147 \mathrm{mg} \mathrm{C} \mathrm{m}^{-2}\right.$, derived from the percentage of total zooplankton biomass in Haga, Nagata \& Sakamoto (1995)]. Bmes = biomass of mesozooplankton [491 $\mathrm{mg} \mathrm{C} \mathrm{m}^{-2}$, Urabe et al. (1995)]. $T$ = average temperature [17.4 ${ }^{\circ} \mathrm{C}, \mathrm{Haga}$ et al. (1995)]. 
fluxes passing through a compartment is called its throughput. It is equal to the sum of entering as well as exiting fluxes for a system at equilibrium. Recycling is carbon involved in cyclic pathways, i.e. carbon coming back to the compartment it left (Ulanowicz, 1986). The cycling activity of each compartment was estimated as the fraction of its throughput involved in recycling (Fasham, 1985). We also estimated the Finn Cycling Index (FCI; Finn, 1976), which is the ratio of the sum of carbon flows in cyclic pathways to the sum of all carbon flows in the system. The ratio detritivory/ herbivory is calculated as the sum of flows of consumption of non-living material divided by the sum of flows of ingestion of autotrophic organisms.

\section{Sensitivity analysis}

A sensitivity analysis was performed to assess the dependence of the calculated fluxes on variations in the values of the field values (right hand value in the equations of Table 4). The 18 data values were varied by $\pm 20 \%$ one at a time and a new set of flows calculated for this perturbed situation. Results for each flow were expressed as a sensitivity index SI (e.g. Richardson et al., 2004):
SI for $i$ th flow $=\left(\left|f_{i, \mathrm{p}}-\mathrm{f}_{\mathrm{i}, \mathrm{o}}\right| / \mathrm{f}_{\mathrm{i}, \mathrm{o}}\right) / 0.2$

where $f_{i, \mathrm{p}}$ and $f_{i, \mathrm{o}}$ are the values for the $i$ th flow in the perturbed and original situations. A value of 1 indicates that the $20 \%$ variation of the field value leads to a $20 \%$ variation in the considered flow value.

The sum of input flows (primary production and imports) was always kept equal to $1674 \mathrm{mg}$ $\mathrm{C} \mathrm{m}^{-2}$ day $^{-1}$. The same was true for the sum of output flows (respiration flows, sinking and exports). When the $+20 \%$ variation increased an input flow, the other input flows were reduced by amounts proportional to their initial values such that the total input was constant. A similar readjustment was made for the $-20 \%$ variation, and for the output flows.

The SI values are averaged per flow, for all the simulations realised and per simulation, for all the obtained flows.

\section{Results}

Input and output flows

The resulting estimates for integrated flows are given in Table 2 and illustrated in Fig. 2. Of the total input

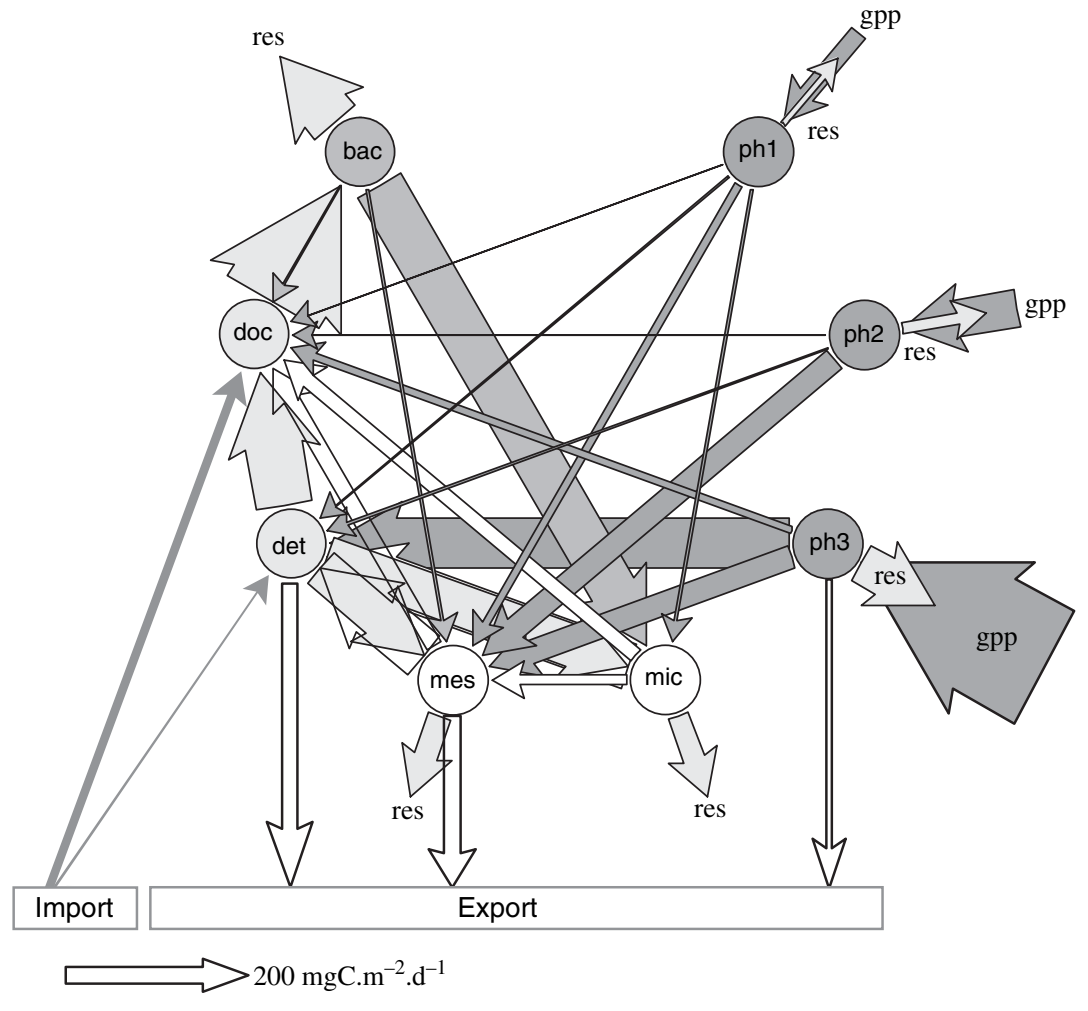

Fig. 2 Inverse solution for the planktonic food web flows in the North Basin of Lake Biwa (20-m layer above the thermocline, during an average summer season). res, respiration flows; gpp, gross primary production flows. Abbreviations for the compartments are given in Table 1. Each carbon flow is represented by an arrow, and the width of each arrow is proportional to the calculated value. 
of $1674 \mathrm{mg} \mathrm{C} \mathrm{m}^{-2}$ day $^{-1}$ to the pelagic community, $66 \%, 19 \%$ and $9 \%$ are from the photosynthetic activities of phytoplankton $>20 \mu \mathrm{m}$, nanophytoplankton $(2-20 \mu \mathrm{m})$ and picophytoplankton $(<2 \mu \mathrm{m})$, respectively. The net allochthonous input of $73 \mathrm{mg}$ $\mathrm{C} \mathrm{m}^{-2}$ day $^{-1}$ for DOC and $23 \mathrm{mg} \mathrm{C} \mathrm{m}{ }^{-2}$ day $^{-1}$ for POC (Yoshimizu et al., 2002; Urabe \& Yoshioka, 2006) is very low compared with primary production.

Respiration flows account for $80 \% \quad(1343 \mathrm{mg}$ $\mathrm{C} \mathrm{m}^{-2}$ day $^{-1}$ ) of the carbon output from the system. Among the living compartments, bacteria have the highest respiration ( $460 \mathrm{mg} \mathrm{C} \mathrm{m}^{-2}$ day $^{-1}$ ), followed by phytoplankton $>20 \mu \mathrm{m}\left(352 \mathrm{mg} \mathrm{C} \mathrm{m}^{-2}\right.$ day $\left.^{-1}\right)$, mesozooplankton (205 $\mathrm{mg} \mathrm{C} \mathrm{m}^{-2}$ day $^{-1}$ ) and microzooplankton (185 $\mathrm{mg} \mathrm{C} \mathrm{m}^{-2}$ day $^{-1}$ ). The remaining $20 \%$ of the output goes to consumption of mes $(149 \mathrm{mg}$ $\mathrm{C} \mathrm{m}^{-2}$ day $^{-1}$, i.e. $9 \%$ ) and sedimentation by detritus (137 $\mathrm{mg} \mathrm{C} \mathrm{m}^{-2}$ day $^{-1}$ ) and phy3 (45 $\mathrm{mg} \mathrm{C} \mathrm{m}^{-2}$ day $^{-1}$ ).

\section{Null flow}

Some allowed flows are zero. This tends to results when there are no data or constraints requiring them. In the present study, there are only two such flows, the sedimentation of phy 2 and ph2 consumption by microzooplankton. The mesozooplankton requirement being high, this group consumed all the available ph2 production, leaving none for microzooplankton. We imposed a combined phy 2 and phy3 sedimentation flux using the results of Nakanishi et al. (1992); the analysis assigned it all to the larger phytoplankton, the ph3. This is reasonable if the nanophytoplankton are efficiently grazed by zooplankton and removed before sinking out.

\section{Throughputs and turnovers}

Six of eight compartments have high throughput values, ranging from 1339 to $805 \mathrm{mg} \mathrm{C} \mathrm{m}^{-2}$ day $^{-1}$ (Table 6). The two highest values (1339 and $1100 \mathrm{mg}$ $\mathrm{C} \mathrm{m}^{-2}$ day $^{-1}$ ) correspond to detrital POC and phytoplankton $>20 \mu \mathrm{m}$. The next, slightly lower values (937-920 $\mathrm{mg} \mathrm{C} \mathrm{m}^{-2}$ day $^{-1}$ ) are for mesozooplankton, DOC and bacteria, followed by microzooplankton $\left(805 \mathrm{mg} \mathrm{C} \mathrm{m}^{-2}\right.$ day $^{-1}$ ). The lowest values are 323 and $155 \mathrm{mg} \mathrm{C} \mathrm{m}{ }^{-2}$ day $^{-1}$, for nanophytoplankton and picophytoplankton, respectively.

There are large differences among the compartments in the turnover rate (throughput divided by
Table 6 Throughputs (sum of entering flows) and turnover rates (biomass/throughput) for each living compartment

\begin{tabular}{lccl}
\hline & $\begin{array}{l}\text { Throughput } \\
\left(\mathrm{mg} \mathrm{C} \mathrm{m}^{-2} \mathrm{day}^{-1}\right)\end{array}$ & $\begin{array}{l}\text { Biomass } \\
\left(\mathrm{mg} \mathrm{C} \mathrm{m}^{-2}\right)\end{array}$ & $\begin{array}{l}\text { Turnover rate } \\
\left(\text { day }^{-1}\right)\end{array}$ \\
\hline ph1 & 155 & $943^{*}$ & 0.16 \\
ph2 & 323 & $616^{*}$ & 0.52 \\
ph3 & 1100 & $1851^{*}$ & 0.59 \\
bac & 920 & $642^{+}$ & 1.43 \\
mic & 805 & 147 & 5.48 \\
mes & 937 & 491 & 1.91 \\
\hline
\end{tabular}

*Urabe et al. (2002); ${ }^{\dagger}$ Urabe et al. (2005).

biomass; Table 6). The picophytoplankton have a very low turnover rate $\left(0.16\right.$ day $\left.^{-1}\right)$ compared with the intermediate values of the other phytoplankton groups. Heterotrophic compartments are high, particularly the microzooplankton who consume 5.48 times their biomass per day. This rate is, however, less than the upper limit of 18 day $^{-1}$ included as a constraint (Table 5).

\section{Internal flows}

Six of the 24 internal flows are $>400 \mathrm{mg} \mathrm{C} \mathrm{m}^{-2}$ day $^{-1}$ : DOC consumption by bacteria ( $920 \mathrm{mg} \mathrm{C} \mathrm{m}^{-2}$ day $^{-1}$ ), detritus degradation to dissolved material $(494 \mathrm{mg}$ $\mathrm{C} \mathrm{m}^{-2}$ day $\left.^{-1}\right)$, loss to detritus by mesozooplankton (437 $\mathrm{mg} \mathrm{C} \mathrm{m}^{-2}$ day $^{-1}$ ), by phytoplankton $>20 \mu \mathrm{m}$ (429 $\mathrm{mg} \mathrm{C} \mathrm{m}^{-2}$ day $^{-1}$ ) and by mesozooplankton (427 mg C m ${ }^{-2}$ day $^{-1}$ ), and consumption of bacteria by mesozooplankton (417 $\mathrm{mg} \mathrm{C} \mathrm{m}^{-2}$ day $^{-1}$ ). All flows affecting detritus are high. The formation of detritus (including organism mortality) makes up 52\% and $47 \%$ of the microzooplankton and mesozooplankton throughputs, respectively. Zooplankton excretion of DOC is also large, $15 \%$ of their totals. As a consequence, the production rates of these two zooplankton compartments are low (10\% and $16 \%$ for mic and mes).

Most carbon photosynthesised by picophytoplankton (ph1) goes to mesozooplankton $(44 \%)$ or is respired $(32 \%)$. The carbon photosynthesised by nanophytoplankton (ph2) goes mostly to mesozooplankton $(63 \%)$. The gross primary production of microphytoplankton (ph3) goes to detritus (39\%), is respired $(32 \%)$, or is consumed by mesozooplankton $(19 \%)$.

The diet of microzooplankton is composed of bacteria $(52 \%)$, followed by detritus $(45 \%)$ and picophytoplankton (3\%). Mesozooplankton ate detri- 
tus $(37 \%)$, microphytoplankton $(22 \%)$, nanophytoplankton $(22 \%)$, microzooplankton $(9 \%)$ picophytoplankton $(7 \%)$ and bacteria $(3 \%)$.

For total consumption in the system, the detritivory/ herbivory ratio is 3.22 , indicating that most heterotrophic production relies on non-living material.

\section{Recycling}

The FCI is $33 \%$, indicating that $33 \%$ of the carbon flows are part of cyclic pathways. The cycling activity of each compartment is $0 \%$ for autotrophs, $41 \%$ and $26 \%$ for POC and DOC, $26 \%$ for bac and $37 \%$ and $23 \%$ for mic and mes.

\section{Sensitivity analysis}

The sensitivity analysis (Table 7) shows that the field input with the greatest impact is the efficiency with which bacteria take up DOC (SI $=2.21)$ followed by bacterial respiration $(\mathrm{SI}=1.66)$, primary production by phytoplankton $>20 \mu \mathrm{m}(\mathrm{SI}=1.45)$, total phytoplankton respiration $(\mathrm{SI}=1.41)$ and bacterial production $(\mathrm{SI}=1.33)$. Numerous perturbations of a field result have a very small effect on the calculated flow values, with SI values between 0.2 and 0.35 . The lowest SI is for the sinking of phytoplankton (0.04).

The flow most affected by changing the input data in the sensitivity analysis is the bac-DOC flow, corresponding to bacterial mortality (mean SI = 6.16), mainly as a result of changing the uptake efficiency of DOC by bacteria. The grazing of picophytoplankton by microzooplankton is the second most affected flow (SI = 2.93), mainly because of its sensitivity to changes in rates of primary production and phytoplankton respiration. The third more sensitive flow is the DOC excretion by microphytoplankton $(\mathrm{SI}=2.83)$.

The detritivory to herbivory ratio varies between 2.55 and 3.52. The smallest value results from decreasing gross primary production by phytoplankton $>20 \mu \mathrm{m}$. The largest value results from increasing DOC uptake efficiency of bacteria.

\section{Discussion}

Several choices were made when developing the $a$ priori model. Our level of aggregation used only three phytoplankton and two zooplankton compartments.
These relatively few groupings cannot fully describe the complex planktonic food web. However, a more detailed food web would require a greater level of experimental data than exists. We did not include the uptake of DOC by protozoa (Sherr \& Sherr, 1988; Marchant \& Scott, 1993) because the process is known to exist in the ocean but we had no information on its extent in lakes. Without any results about its size over even enough information to constrain the flow, we could not represent it adequately. As noted earlier, we did not include the flow of material directly from detritus because it was represented by flow through detritus to DOC.

We did not include fish feeding directly because it was represented as an outflow of carbon. This description of the role of fish implies that they do not graze on the other planktonic organisms nor do they provide an additional carbon source as a result of migrations to either the benthos of the littoral zone and subsequent egestion. Any additional inputs of detrital material would only reinforce the main characteristic of a system highly relying on the consumption of non-living material.

Comparative data are needed to discuss the emergent properties. In order to do so, we built a comparative Table 8 using two different approaches, both for mass balances models. The first one consisted in taking directly indices published in the literature about lake planktonic food webs at different periods for Lakes Paul (WI, U.S.A.) and Konstanz (Germany and Switzerland). Vézina \& Pace (1994) estimated flows during three consecutive years for Lake Paul using an inverse analysis. The results presented here represent the ranges of values for those 3 years. Gaedke \& Straile (1994) made their own estimates of monthly flows for Lake Konstanz from measurements and literature data. The results in Table 8 are for their summer period.

The second approach for accumulating values of emergent properties was to calculate indices using network analysis when the published flow values had sufficient detail. The only lake where such data are available is Lake Kinneret (Israel; Stone et al., 1993), for which a method of linear programming similar to our inverse analysis was used to describe an average year. The results in Table 8 concern the Lake Kinneret model for August to September. The results for three other, non-lacustrine; planktonic food webs were added to the comparison, all concerning whole-year 
Table 7 Result of the sensitivity analysis. Each field estimate (right hand value in Table 4) is modified by minus (-) or plus (+) $20 \%$

\begin{tabular}{|c|c|c|}
\hline & SI & $\mathrm{D} / \mathrm{H}$ \\
\hline \multicolumn{3}{|c|}{ Gross primary production of ph1 and ph2 } \\
\hline- & 0.62 & 3.04 \\
\hline+ & 0.84 & 2.80 \\
\hline \multicolumn{3}{|c|}{ Gross primary production of ph3 } \\
\hline- & 1.45 & 2.55 \\
\hline+ & NS & NS \\
\hline \multicolumn{3}{|c|}{ Total sinking } \\
\hline- & NS & NS \\
\hline+ & 0.35 & 3.06 \\
\hline \multicolumn{3}{|c|}{ Sinking of phytoplanktonic cells (ph2 and ph3) } \\
\hline- & 0.04 & 3.22 \\
\hline+ & 0.04 & 3.22 \\
\hline \multicolumn{3}{|c|}{ Respiration of phytoplankton } \\
\hline- & 1.41 & 2.85 \\
\hline+ & NS & NS \\
\hline \multicolumn{3}{|c|}{ Respiration of bacteria } \\
\hline- & NS & NS \\
\hline+ & 1.66 & 3.34 \\
\hline \multicolumn{3}{|c|}{ Respiration of zooplankton } \\
\hline- & NS & NS \\
\hline+ & NS & NS \\
\hline \multicolumn{3}{|c|}{ Exudation of DOC by the phytoplankton } \\
\hline- & 0.13 & 3.18 \\
\hline+ & 0.31 & 3.13 \\
\hline \multicolumn{3}{|c|}{ POC egestion by zooplankton } \\
\hline - & 0.33 & 2.90 \\
\hline+ & 0.35 & 3.41 \\
\hline \multicolumn{3}{|c|}{ Grazing of ph1 by mesozooplankton } \\
\hline - & 0.33 & 3.15 \\
\hline+ & 0.33 & 3.15 \\
\hline \multicolumn{3}{|c|}{ Grazing of ph2 by mesozooplankton } \\
\hline- & 0.84 & 3.15 \\
\hline+ & NS & NS \\
\hline \multicolumn{3}{|c|}{ Grazing of ph3 by mesozooplankton } \\
\hline- & 0.27 & 3.50 \\
\hline+ & 0.31 & 2.85 \\
\hline \multicolumn{3}{|c|}{ Bacterial production } \\
\hline - & 1.33 & 3.20 \\
\hline+ & NS & NS \\
\hline \multicolumn{3}{|c|}{ Mesozooplankton production } \\
\hline- & 0.29 & 3.30 \\
\hline+ & 0.29 & 3.14 \\
\hline \multicolumn{3}{|c|}{ Carbon import as POC and DOC } \\
\hline - & 0.20 & 3.16 \\
\hline+ & 0.20 & 3.28 \\
\hline \multicolumn{3}{|c|}{ Carbon import as POC } \\
\hline - & 0.26 & 3.15 \\
\hline+ & 0.25 & 3.16 \\
\hline \multicolumn{3}{|c|}{ DOC consumption by bacteria } \\
\hline - & NS & NS \\
\hline+ & 2.21 & 3.52 \\
\hline \multicolumn{3}{|c|}{ Bacteria grazing efficiency by mesozooplankton } \\
\hline - & 0.26 & 3.15 \\
\hline+ & 0.25 & 3.15 \\
\hline
\end{tabular}

SI = Sensitivity Index, averaged for all the flows of the simulated model. NS means that there was no solution to the system of equations with the constraints. $\mathrm{D} / \mathrm{H}=$ ratio detritivory/herbivory. 
N. Niquil et al.

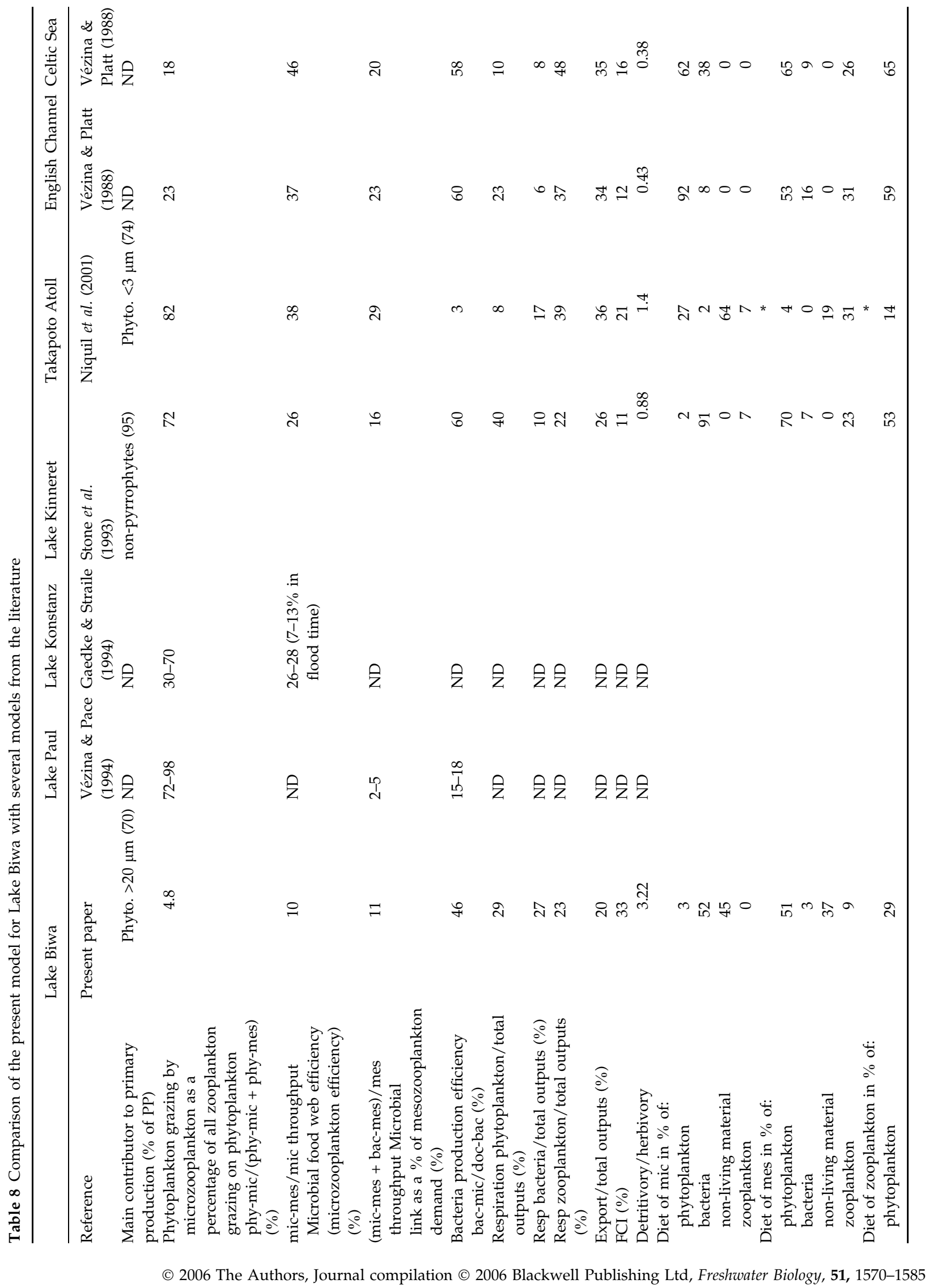




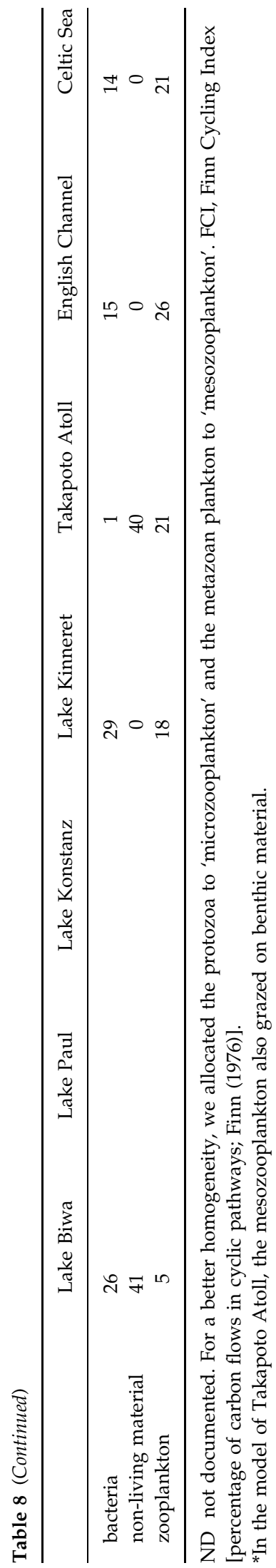

food webs obtained by inverse analysis, i.e. the lagoon of Takapoto Atoll (French Polynesia; Niquil et al., 2001) and models of euphotic zones in the English Channel and the Celtic Sea (Vézina \& Platt, 1988).

The main source of carbon in Lake Biwa is photosynthesis by microphytoplankton $(>20 \mu \mathrm{m})$. Phytoplankton were not separated into size fractions in the published lake models. Stone et al. (1993) did separate pyrrophyte and non-pyrrophyte nanoplanktonic algae in their models of Lake Kinneret for March to April and August to September. The relative contributions of these two groups were very different in the two periods, with non-pyrrophyte nanoalgae representing $27 \%$ of photosynthesis in March to April and $95 \%$ in August to September. Photosynthesis during the summer is dominated by larger algae in Lake Biwa, unlike Lake Kinneret, but its variability is larger at Lake Kinneret.

Two of these studies included non-photosynthetic inputs. In Takapoto, grazing of mesozooplankton on the benthos was an important input. In Lake Biwa, non-photosynthetic inputs represent only $6 \%$ of the total input. The dominance of the $>20 \mu \mathrm{m}$ phytoplankton results large consumption of autotrophic organisms by mesozooplankton $(51 \%$ of their diet, Table 8). This dominance was even stronger in Lake Kinneret, but the consumption of detritus by zooplankton was not considered as a possible flow in that study (Stone et al., 1993).

Carbon from the planktonic system of Lake Biwa leaves evenly distributed among phytoplankton, bacteria, zooplankton respiration and export (sinking, and consumption of mesozooplankton production by non-planktonic animals). The main differences between it and Lake Kinneret are the higher phytoplankton respiration and lower bacterial respiration at Lake Kinneret, whereas zooplankton respiration is similar fraction of carbon outputs in both. In the studies of marine environments, phytoplankton and bacterial respiration were less important in carbon output than in Lake Biwa and zooplankton were mostly responsible for the removal of carbon.

In Lake Biwa, the direct link from phytoplankton to zooplankton is less important than the indirect link through non-living compartments, comprising two pathways: direct consumption of particulate detritus by meso- and microzooplankton and their consumption of bacteria. Bacterial production depends on the DOC excreted by the various living and dead com- 
partments. The bacterial path is important in Lake Biwa, with major pathways going from living compartments to particulate detritus to DOC to bacteria, which are in turn consumed by microzooplankton. Thus, detritivory in one form or another plays a major role in secondary production. However, micro- and mesozooplankton differ in their use of newly photosynthesised versus recycled matter in their diets. Autotrophic matter is available mainly as phytoplankton $>20 \mu \mathrm{m}$, which is grazed mostly by mesozooplankton. As a result, phytoplankton represent 3\% and $51 \%$ of micro- and mesozooplankton diet. Because of the production rates for phytoplankton $<20 \mu \mathrm{m}$, microzooplankton must rely on detritus and bacteria.

Given the species composition of mesozooplankton, the conclusion that the microbial assemblage contributes little to the diet of mesozooplankton is reasonable. From June to September, a calanoid copepod, E. japonicus, is the dominant mesozooplankter (Yoshida et al., 2001a). This species grazes minimally on bacteria (Nagata \& Okamoto, 1988). In addition, Nagata et al. (1996) showed experimentally that small flagellates accounted for $<5 \%$ of the total carbon consumption by mesozooplankton when E. japonicus was dominant. Eodiaptomus japonicus can stimulate the growth rate of bacteria, probably thorough nutrient regeneration and substrate supply (Yoshida et al., 2001b). Our results, together with those of previous studies, imply that the microbial assemblage predominantly respire carbon and regenerate nutrients, with only a relatively small flow to higher trophic levels, especially when calanoid copepods are dominant. There are several indices in the literature for estimating the importance of the microbial food web in the functioning of the plankton community. Gaedke \& Straile (1994) used microbial food web efficiency, the ratio is the consumption of microzooplankton by mesozooplankton divided by the ingestion by microzooplankton (or its throughput). They describe this ratio as the quantification of how much microzooplankton makes the organic carbon available to macro-consumer. According to this ratio, Lake Biwa is the least efficient of systems in Table 7 at transferring carbon from microzooplankton to mesozooplankton. Although the throughput of microzooplankton is very high, the carbon goes mainly to detritus, DOC, and respiration. Only $10 \%$ of the microzooplankton throughput is transferred directly to mesozooplank- ton. The one system with similar values for this index $(7-13 \%)$ is the period following a summer flood in Lake Konstanz.

Vézina \& Pace (1994) used a different index for estimating the microbial link. They calculate the consumption of heterotrophic microorganisms (bacteria and microzooplankton) by mesozooplankton as a percentage of mesozooplankton ingestion. This index is similar for Lake Biwa and marine systems. The difference between Lake Biwa and Lake Kinneret in August to September is not as strong as for the microbial food web efficiency previously discussed, but points in the same direction, i.e. a lowest efficiency of transfer from heterotrophic microorganisms to the macro-consumer in Lake Biwa. The index indicates that Lake Paul (Vézina \& Pace, 1994) had an even lower efficiency than Lake Biwa.

Despite a high activity of bacteria and microzooplankton (dominated by protozoa), the dominant link to macro-consumers is not through the consumption of bacteria or microzooplankton, but through direct consumption of detritus by mesozooplankton. This may reflect the inability of mesozooplankton to graze efficiently on large algae. Also, the present results explain why the sinking flow was as low as $11 \%$ of primary production in spite of predominance of large less efficiently grazed algae: carbon in these algae was grazed after entering the detrital pool. Predominance of such large algae is a characteristic of the Lake Biwa plankton community (Kawabata \& Nakanishi, 1994).

This interpretation about the dominance of recycling in the functioning of the Lake Biwa planktonic system is reinforced by the comparison of two network analysis indices, i.e. the FCI, which calculates the percentage of carbon flows involved in cyclic pathways and the ratio of detritivory to herbivory. These two indices are very high for Lake Biwa relative to both Lake Kinneret and marine systems (Table 8). The very high FCI in Lake Biwa stresses the importance of recycling compared with direct consumption of autotrophic compartments. The ratio detritivory/ herbivory is even higher than the value observed in the lagoon of Takapoto Atoll, whereas this coral reef system highly depends on the consumption of detrital material for sustaining its high activity. This pattern is consistent with the above description of the planktonic system in Lake Biwa, which is based on high recycling of organic matter; the latter relies on direct consumption of detrital carbon by the heterotrophic 
compartments. This conclusion is robust, as the detritivory to herbivory ratio is very high for all the simulations of the sensitivity analysis.

The use of the inverse analysis for estimating missing flow value was essential in this case, even if many of the flows were already well documented. The flows involving detritus were deduced from the calculation (i.e. from field data and physiological constraints), despite our inability to experimentally discriminate of living from non-living fine particles.

Detritus has a prominent role in this system with relatively low allochtonous carbon inputs. However, it could be more general observation as non-living particulate matter usually makes up a majority of the carbon content in lakes and most mesozooplankton cannot discriminate between living and non-living particles within their edible size ranges. This role for detritus in lakes is consistent with recent results showing the potential important place of detritus in mesozooplankton diet (Jeppesen et al., 1999; Pilati, Wurtsbaugh \& Brindza, 2004). It may be even stronger than observed in marine ecosystems (Lampitt, Noji \& von Bodungen, 1990; Maar et al., 2004). However, experimental confirmation of this detritivory for mesozooplankton and, especially, microzooplankton in Lake Biwa would be of great interest.

\section{Acknowledgments}

The authors thank the Lake Biwa Research Institute for financial supported of this work through the Cyanobacteria Risk Assessment in Biwako program and the two anonymous reviewers for useful remarks.

\section{References}

Eldridge P.M. \& Jackson G.A. (1993) Benthic trophic dynamics in California coastal basin and continental slope communities inferred using inverse analysis. Marine Ecology Progress Series, 99, 115-135.

Fasham M.J.R. (1985) Flow analysis of material in the marine euphotic zone. Canadian Bulletin of Fisheries and Aquatic Sciences, 213, 139-162.

Finn J.T. (1976) Measures of ecosystem structure and function derived from analysis of flows. Journal of Theoretical Biology, 56, 363-380.

Frenette J.-J., Vincent W.F. \& Legendre L. (1996) Sizedependent changes in phytoplankton $\mathrm{C}$ and $\mathrm{N}$ uptake in the dynamic mixed layer of Lake Biwa. Freshwater biology, 36, 221-236.
Gaedke U. \& Straile D. (1994) Seasonal changes of the quantitative importance of protozoans in a large lake. An ecosystem approach using mass-balanced carbon flow diagrams. Marine Microbial Food Webs, 8, 163-188.

Gurung T.B. \& Urabe J. (1999) Temporal and vertical difference in factors limiting growth rate of heterotrophic bacteria in Lake Biwa. Microbial Ecology, 38, 136-145.

Gurung T.B., Nakanishi M. \& Urabe J. (2000) Seasonal and vertical difference in negative and positive effects of grazers on heterotrophic bacteria in Lake Biwa. Limnology Oceanography, 45, 1689-1696.

Gurung T.B., Kagami M., Yoshida T. \& Urabe J. (2001) Relative importance among biotic and abiotic factors affecting bacterial abundance in Lake Biwa: an empirical analysis. Limnology, 2, 19-28.

Gurung T.B., Urabe J., Nozaki K. \& Yoshimizu C., Nakanishi M. (2002) Bacterioplankton production in a water column of Lake Biwa. Lakes \& Reservoirs, 7, 317323.

Haga H., Nagata T. \& Sakamoto M. (1995) Sizefractionated $\mathrm{NH}_{4}^{+}$regeneration in the pelagic area of two mesotrophic lakes. Limnology Oceanography, 40, 1091-1099.

Jeppesen E., Jensen J.P., Søndergaard M. \& Lauridsen T. (1999) Trophic dynamics in turbid and clearwater lakes with special emphasis on the role of zooplankton for water clarity. Hydrobiologia, 408-409, 217-231.

Kagami M. \& Urabe J. (2001) Phytoplankton growth rate as a function of cell size: an experimental test in Lake Biwa. Limnology, 2, 111-117.

Kagami M., Yoshida T., Gurung T.B. \& Urabe J. (2002) Direct and indirect effects of zooplankton on algal composition in in situ-grazing experiments. Oecologia, 133, 356-363.

Kawabata K. (1987) Abundance and distribution of Eodiaptomus japonicus (Copepoda: Calanoida) in Lake Biwa. Bulletin of the Plankton Society of Japan, 34, 173183.

Kawabata K. \& Nakanishi M. (1994) Food web structure and biodiversity in lake ecosystems. In: Biodiversity, $A n$ Ecological Perspective (Eds T. Abe, S.A. Levin \& M. Higashi), pp. 203-214. Springer, Berlin.

Kawabata K. \& Urabe J. (1996) Population dynamics of planktonic crustacea studied during BITEX 93. Japanese Journal of Limnology, 4, 545-552.

Lampitt R.S., Noji T. \& von Bodungen B. (1990) What happens to zooplankton faecal pellets? Implications for material flux. Marine Biology, 104, 15-23.

Maar M., Nielsen T.G., Gooding S., Tönnesson K., Tiselius P., Zervoudaki S., Christou E. \& Richardson K. (2004) Trophodynamic function of copepods, appendicularians and protozooplankton in the late 
summer zooplankton community in the Skagerrak. Marine Biology, 144, 917-933.

Marchant H.J. \& Scott F.J. (1993) Uptake of submicrometre particles and dissolved organic material by Antarctic choanoflagellates. Marine Ecology Progress Series, 92, 59-64.

Mitamura O., Kawashima M. \& Maeda H. (2000) Urea degradation by picophytoplankton in the euphotic zone of Lake Biwa. Limnology, 1, 19-26.

Nagata T. (1984) Bacterioplankton in Lake Biwa: annual fluctuations of bacterial numbers and their possible relationship with environmental variables. Japanese Journal of Limnology, 45, 126-133.

Nagata T. (1986) The seasonal abundance and vertical distribution of the $<3-\mu \mathrm{m}$ phytoplankton in the North Basin of Lake Biwa. Ecological Research, 1, 207-221.

Nagata T. (1988) The microflagellate-picoplankton food linkage in the water column of Lake Biwa. Limnology Oceanography, 33, 504-517.

Nagata T. \& Okamoto K. (1988) Filtering rates on natural bacteria by Daphnia longispina and Eodiaptomus japonicus in Lake Biwa. Journal of Plankton Research, 10, 835850.

Nagata T., Takai K., Kawabata K.-I., Nakanishi M. \& Urabe J. (1996) The trophic transfer via a picoplanktonflagellate-copepod food chain during a picocyanobacterial bloom in Lake Biwa. Archiv fur Hydrobiologie, 137, 145-160.

Nakanishi M., Tezuka Y., Narita T., Mitamura O., Kawabata K. \& Nakano S.-I. (1992) Phytoplankton primary production and its fate in a pelagic area of Lake Biwa. Archiv für Hydrobiologie Beiheft Ergebnisse der Limnologie, 35, 47-67.

Nakano S.-I. (1992) Changes in bacterioplankton production and dominant algal species in the North Basin of Lake Biwa. Japanese Journal of Limnology, 53, 145-149.

Nakano S.-I. (1994) Rates and ratio of nitrogen and phosphorus released by a bacterivorous flagellate. Japanese Journal of Limnology, 55, 115-123.

Niquil N., Arias-González J.E., Delesalle B. \& Ulanowicz R.E. (1999) Characterization of the planktonic food web of Takapoto Atoll lagoon, using network analysis. Oecologia, 118, 232-241.

Niquil N., Jackson G.A., Legendre L. \& Delesalle B. (1998) Inverse model analysis of the planktonic food web of Takapoto Atoll (French Polynesia). Marine Ecology Progress Series, 165, 17-29.

Niquil N., Pouvreau S., Sakka A., Legendre L., Addessi L., Le Borgne R., Charpy L. \& Delesalle B. (2001) Trophic web and carrying capacity in a pearl oyster farming lagoon (Takapoto, French Polynesia). Aquatic Living Resources, 14, 165-174.
Pilati A., Wurtsbaugh W.A. \& Brindza N.R. (2004) Evidence of coprophagy in freshwater zooplankton. Freshwater Biology, 49, 913-918.

Richardson T.L., Jackson G.A., Ducklow H.W. \& Roman M.R. (2004) Carbon fluxes through food webs of the eastern equatorial Pacific: an inverse approach. DeepSea Research I, 51, 1254-1274.

Robarts R.D., Waiser M.J., Hadas O., Zohary T. \& MacIntyre S. (1998) Relaxation of phosphorus limitation due to typhoon-induced mixing in two morphologically distinct basins of Lake Biwa, Japan. Limnology Oceanography, 43, 1023-1036.

Sherr E.B. \& Sherr B.F. (1988) Role of microbes in pelagic food webs: a revised concept. Limnology Oceanography, 33, 1225-1227.

Stone L., Berman T., Bonner R., Barry S. \& Weeks S.W. (1993) Lake Kinneret: A seasonal model for carbon flux through the planktonic biota. Limnology Oceanography, 38, 1680-1695.

Takahashi M., Hama T., Matsunaga K. \& Handa N. (1995a) Nitrogenous nutrient uptake by phytoplankton and ammonium regeneration by microbial assemblage in Lake Biwa. Journal of Plankton Research, 17, 10271037.

Takahashi M., Hama T., Matsunaga K. \& Handa N. (1995b) Photosynthetic organic carbon production and respiratory organic carbon consumption in the trophogenic layer of Lake Biwa. Journal of Plankton Research, 17, 1017-1025.

Ulanowicz R.E. (1986) Growth E Development: Ecosystems Phenomenology. Springer-Verlag, New York, 203 p.

Ulanowicz R.E. (1999) NETWRK 4.2 a Package of Computer Algorithms to Analyse Ecological Flow Networks. http:/ / www.cbl.umces.edu/ ulan/ntwk/network.html.

Urabe J. \& Watanabe Y. (1990) Difference in the bacterial utilization ability of four cladoceran planktonn (Crustacea: Cladocera). Natural History Research, 1, 85-92.

Urabe J. \& Yoshioka T. (2006) Carbon metabolisms and ecosystem function of lakes. In: Land Ecosystem Sciences Under Global Environmental Changes (Eds H. Takeda \& J. Urabe), pp. 156-185. Kyoritsu Shuppan, Tokyo, Japan.

Urabe J., Gurung T.B. \& Yoshida T. (1999b) Effects of phosphorus supply on phagotrophy by the mixotrophic alga Uroglena americana (Chrysophyceae). Aquatic Microbial Ecology, 18, 77-83.

Urabe J., Nakanishi M. \& Kawabata K. (1995) Contribution of metazoan plankton to the cycling of nitrogen and phosphorus in Lake Biwa. Limnology Oceanography, 40, 232-241.

Urabe J., Kawabata K., Nakanishi M. \& Shimizu K. (1996) Grazing and food size selection of zooplankton 
community in Lake Biwa during BITEX '93. Japanese Journal of Limnology, 57, 27-37.

Urabe J., Yoshida T., Gurung T.B., Kagami M., Sekino T. \& Nakanishi M. (2002) Biomass ratio of plankton and current status in Lake Biwa. Global Environmental Research, 7, 37-45.

Urabe J., Sekino T., Nozaki K., Tsuji A., Yoshimizu C., Kagami M., Koitabashi T., Miyazaki T. \& Nakanishi M. (1999a) Light, nutrients and primary productibity in Lake Biwa: An evaluation of the current ecosystem situation. Ecological Research, 14, 233242.

Urabe J., Yoshida T., Gurung T.B., Sekino T., Tsugeki N., Nozaki K., Maruo M., Nakayama E. \& Nakanishi M. (2005) The production-to-respiration ratio and its implication in Lake Biwa, Japan. Ecological Research, 20, 367-375.

Vézina A.F. (1989) Construction of flow networks using inverse methods. In: Network Analysis in Marine Ecology (Eds F. Wulff, J.G. Field \& K.H. Mann), pp. 62-81. Springer-Verlag, Berlin.

Vézina A.F. \& Pace M.L. (1994) An inverse model analysis of planktonic food webs in experimental lakes. Canadian Journal of Fisheries and Aquatic Sciences, 51, 2034-2044.
Vézina A.F. \& Platt T. (1988) Food web dynamics in the oceans. 1. Best-estimates of flow networks using inverse methods. Marine Ecology Progress Series, 42, 269-287.

Yoshida T., Gurung T.B., Kagami M. \& Urabe J. (2001b) Contrasting effects of a cladoceran (Daphnia galeata) and a calanoid copepod (Eodiaptomus japonicus) on algal and microbial plankton in a Japanese lake, Lake Biwa. Oecologia, 129, 602-610.

Yoshida T., Kagami M., Gurung T.B. \& Urabe J. (2001a) Seasonal succession of zooplankton in the north basin of Lake Biwa. Aquatic Ecology, 35, 19-29.

Yoshimizu C., Yoshida T., Nakanishi M. \& Urabe J. (2001) Effect of zooplankton on the sinking flux of organic carbon in Lake Biwa. Limnology, 2, 37-43.

Yoshimizu C., Urabe J., Sugiyama M., Maruo M., Nakayama E. \& Nakanishi M. (2002) Carbon and phosphorus budgets in pelagic area of Lake Biwa, the largest lake in Japan. Verhandlungen - Internationale Vereinigung für theoretische und angewandte Limnoloqie, 28, 1409-1414.

(Manuscript accepted 4 June 2006) 